\title{
Intercropping aromatic plants with coffee (Coffea arabica L.) under greenhouse and field conditions
}

\author{
Cultivo asociado de plantas aromáticas con café \\ (Coffea arabica L.) bajo condiciones de invernadero y campo
}
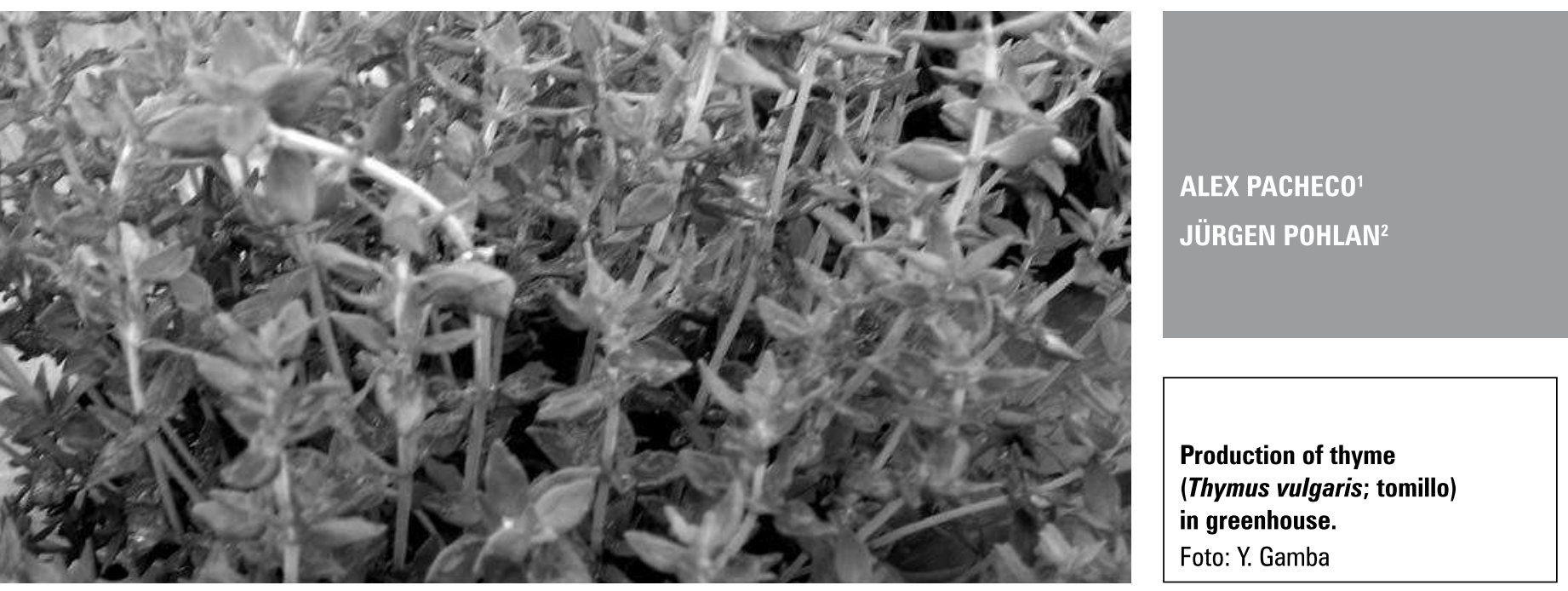

\begin{abstract}
Most of the natural products that cause allelopathy are secondary metabolism compounds synthesized by plants and microorganisms, and most of the currently identified are present in aromatic plants. Allelopathic and autotoxic effects of coffee plants are well known due to production and accumulation of caffeine in a soluble form in soil. Intercropping aromatic plants with coffee provides some advantages, such as weed control, nutrient recycling, low-external input farming, and extra income for the idle area, but allelopathic interactions are need to be identified. The obtained results in this study didn't show evidence of negative influence from the age of cultivars and accumulation of caffeine in the soil on yield production of aromatic plants. Potential detoxification of caffeine through sage, thyme, and rosemary may diminish toxic accumulation of the allelochemicals in old coffee plantations and increase the production. Results demonstrated the high potential of intercropping coffee with spearmint, basil, and oregano to increase yield production, reduce idle area, and increase profit margins for the small coffee producers.
\end{abstract}

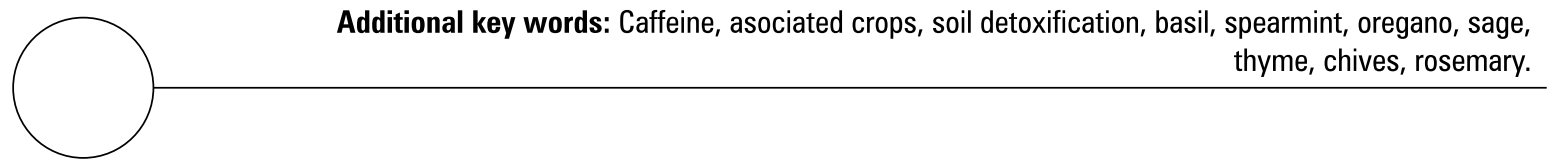

Researcher, Institute of Crop Science and Resource Conservation, University of Bonn, Bonn, Germany. alexpacheco@hotmail.com

2 Professor, Institute of Crop Science and Resource Conservation, University of Bonn, Bonn, Germany. drjpohlan@excite.com 


\section{RESUMEN}

La mayor parte de los productos naturales que causan alelopatía son compuestos del metabolismo secundario sintetizados por plantas y microorganismos, la mayoría de los identificados actualmente están presentes en plantas aromáticas. Los efectos alelopáticos y autotóxicos en plantas de café son bien conocidos debido a la producción y acumulación de cafeína en forma soluble en el suelo. El intercalado de plantas aromáticas con café ofrece algunas ventajas como el control de malezas, reciclaje de nutrientes, agricultura con bajo uso de insumos externos e ingreso adicional para el área inutilizada, pero las interacciones alelopáticas deben identificarse. Los resultados obtenidos en este estudio no evidenciaron influencia negativa en el rendimiento de plantas aromáticas en relación con la edad de los cultivos de café y la acumulación de cafeína en el suelo. La desintoxicación potencial de cafeína a través de la salvia, el tomillo y el romero puede disminuir la acumulación tóxica del aleloquímico en cafetales viejos y aumentar la producción. Los resultados demuestran el alto potencial que tiene intercalar café con menta, albahaca y orégano, para aumentar producción y reducir el área inutilizada, a la vez que se aumentan los ingresos de los minifundistas cafeteros.

Palabras clave adicionales: Cafeína, cultivos asociados, desintoxicación de suelos, albahaca, menta, orégano, salvia, tomillo, romero.

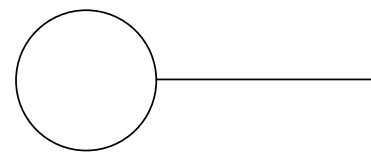

INTRODUCTION

For many countries, industry of coffee (Coffea arabica L.) is a significant source of revenue and a source of employment in rural communities. A crisis in the sector, as in present days, creates social disbalances, instability, and migration accelerated to urban areas (Cardenas, 2003; Pohlan, 2002). If crisis continues, coffee growers in Latin America will be forced to abandon their plantations and look for alternative activities, such as cultivation of illegal crops (Pohlan, 2001). Some coffee growers that confront the crisis have begun to diversify their crops with cultivation of medicinal and aromatic plants as intercrops. Intercalating aromatic plants provides some advantages, such as control of weeds, recycling of nutrients, use of unproductive areas, and extra income (Chou y Waller, 1980; Chou, 1986; Rizvi and Rizvi, 1987).
The heft of natural products that cause allelopathie aresecondarymetabolismcompoundssynthesized by plants and microorganisms and identified as cyanic and benzoic acids, tannins, flavonoids, terpenoids, few alkaloids, steroids, and quinons (Einhelling and Leather, 1988; Phippen and Simon, 1998; 2000). Phenolic complexes and series of natural products, including polyphenols, such as flavonoids and antocianins, mainly compose aromatic plants (Phippen and Simon, 1998).

In addition, caffeine is a powerful compound, which allelopathic and autotoxic effects are known in coffee plantations (Anaya et al., 2002; Rizvi and Rizvi, 1987; Suzuki and Waller, 1987). Friedman and Waller (1983; 1983a) showed that caffeine inhibits the mitosis in lettuce (Lactuca sativa L.) roots reducing the access of nutrients and water. 
The researchers indicated that freed caffeine from decaying seeds and leaves is accumulated in a soluble form in the ground. Autotoxicity is one of principal problems in coffee soils when $150-200 \mathrm{~g}$ coffee dry matter liberate about 1-2 g caffeine, per $\mathrm{m}^{2}$ and year, creating limitations in production. Waller et al. (1986) demonstrated that caffeine applied externally was absorbed and translocated by the radical system of coffee (Coffea arabica L. Bourbon variety), however, he did not carry out an investigation if caffeine was accumulated or metabolized in primary compounds, such as sugars. These processes of detoxification are largely distributed in the plant kingdom and make plants possible to grow in adverse environments and conditions. This property can be present in aromatic plants, too.

The present study was focused on the adaptability of seven aromatic species, spearmint (Mentha piperita L.) Italian and Genovese basil (Ocimum basilicum L.), chives (Allium schoenoprasum L.), oregano (Origanum vulgare L.) thyme (Thymus vulgaris L.), sage (Salvia officinalis L.) and rosemary (Rosmarinus officinalis L.) intercropped with coffee (Coffea arabica L.) under controlled and field conditions to evaluate potential allelopathic relations.

\section{MATERIALS AND METHODS}

\section{Greenhouse experiments}

The first experiment was done in the greenhouse of the University of Bonn, at the experimental farm, Marhof in Wesseling/Germany from February to August 2003. Aromatic plants of four species, of an elderly month, were intercalated with oneyear-old coffee plants in $32 \mathrm{~cm}$ diameter and 40 $\mathrm{cm}$ height pots.

The following five treatments were evaluated: (A1) coffee without aromatic plants, (A2) coffee with spearmint, (A3) coffee with salvia, (A4) coffee with chives, and (A5) coffee with rosemary.
The experiment was distributed in randomized blocks with five repetitions per treatment with a density of four aromatic plants and one of coffee per pot. Commercial soil with an application of commercial fertilizer (15-15-15 in doses of $50 \mathrm{~g} / \mathrm{plot}$ at 105 day after transplanting) was used. Pots were irrigated weekly. The following physiological variables were taken in coffee 145 days after transplanting: (a) number of branches, (b) height of plants $(\mathrm{cm})$, and, in aromatic plants, (a) leaf biomass ( $g / p o t)$.

The second measurement was done 195 days after transplanting with the independent harvest of the radicle system and aerial system measuring the following variables in coffee: (a) number of branches, (b) plant height (cm), (c) shoot diameter $(\mathrm{mm})$, (d) leaf biomass, and (e) root biomass ( $\mathrm{g} /$ plant), and, in aromatic plants, (a) plantheight $(\mathrm{cm})$, (b) leaf biomass, and (c) root biomass ( $\mathrm{g} /$ plant).

\section{Field experiments}

Second part of investigation was done in the farm Argovia, Chiapas/Mexico between May and August 2003. The farm is located at $1507^{\prime} 962$ north latitude and 92 18'177 length west with an altitude of $622 \mathrm{~m}$ above sea level. The soil analysis is presented in the table 1 . The climate was classified as hot semi-humid with abundant rains in summer. Annual temperature mean varied strongly according to the height, showing in the coffee region an average of $20^{\circ} \mathrm{C}$. The precipitation mean was 3,800-4,000 mm per year.

Between the evaluated factors, factor A was the following one: seven species of aromatic plants were intercropped in three different coffee systems. Randomized blocks with three repetitions for experimental unit were used. The following treatments were evaluated: (A1) coffee without aromatic plants, (A2) coffee with Italic basil, (A3) coffee with spearmint, (A4) coffee with Genovese basil, (A5) coffee with sage, (A6) coffee with thyme, (A7) coffee with oregano, (A8) Coffee with chives, and (A9) coffee with rosemary. 
The factor B included the effects of different coffee systems in parameters of growth in aromatic plants: (B1) nursery, coffee plants of a year, (B2) new plot, coffee plants of four old years, and (B3) old plot, coffee plants of ten year old.

In the nursery, on the area of $38 \mathrm{~m} 2$ three randomized repetitions in blocks with experimental units composed of nine aromatic plants and four coffee plants were used. The space of $0,5 \mathrm{~m}$ was left among the plants.

The other two experiments were located in productive plots with an area of $96 \mathrm{~m}^{2}$. The experimental units were distributed among the coffee rows, using an arrangement of complete randomized blocks with a size of $2 \times 1 \mathrm{~m}$ for each treatment with three repetitions for treatment. The density of experimental units was 13 aromatic plants sown on $0.40 \times 0.40 \mathrm{~cm}$ area and six coffee plants sown on $2 \times 2 \mathrm{~m}$ area for each treatment. A clearance of $2 \mathrm{~m}$ among experimental units and a strep among repetitions were left.

Six week old aromatic plants, obtained from commercial growers were established in experimental arrangements. Two fertilization times, the first with $500 \mathrm{~g} /$ plant of compost and the second, 30 days after transplanting, with 50 g/plant of commercial fertilizer (18 N - 18 P - 18 $\mathrm{K})$ were applied. The pest and diseases handling were done with Mancozeb, Endosulfan, and Parathion-methyl.

The following variables were measured in coffee: (a) number of beans without physical damage per marked branch, (b) number of leaves without physical damage per marked branch, (c) length of marked branches (cm), (d) total number of branches per plant, and (e) total number of beans per plant, and, in aromatic plants: (a) plant height (cm) and (b) diameter (cm).

The harvest was carried out 55 days after transplanting. Fresh matter of shoot and root systems was harvested separately and evaluated per $\mathrm{m}^{2}$. The following variables in the harvest were evaluated the leaf and root fresh matter $(\mathrm{g})$.

\section{Laboratory experiments}

In order to determine absorption the possibilities and possible detoxification of caffeine, six weeks old aromatic plants of seven different species (spearmint, chives, rosemary, thyme, oregano, basil, and sage) were utilized. Plants were transferred to $500 \mathrm{~mL}$ beakers and the root system was submerged into $0,100,500 \mu \mathrm{M}$ caffeine solutions with artificial aeration and growing medium after Waller protocol (Waller et al., 1983). The exposure time was $24 \mathrm{~h}$. In order to prevent evaporation and changes in the concentrations of caffeine, the beakers were closed with waxed paper.

In order to estimate the caffeine absorption, seedling radicle and aerial systems were harvested independently. Compounds were extracted through methanolic method and identified with HPLC analysis as follows:

Methanolic extraction: The vegetable material was transferred to a mortar and homogenized with $50 \%$ of Methanol and quartz sand. The mixture was filtered (filter paper 400 Calbiochem). After centrifugation to $10,000 \mathrm{G}$ during $15 \mathrm{~min}$ the

Table 1. Properties of soil at Argovia farm, Tapachula, Mexico*.

\begin{tabular}{|r|r|r|r|r|r|r|r|}
\hline$\%$ Sand & $\%$ Loam & \% Clay & Texture & O.M. (\%) & Org. C * $(\%)$ & C/N & N (\%) \\
\hline 47.48 & 35.36 & 20.18 & Loam & 4.37 & 2.60 & 11.07 & 0.41 \\
\hline $\mathrm{P}(\mathrm{mg} / \mathrm{kg})$ & $\mathrm{K}(\mathrm{cmo} / \mathrm{kg})$ & $\mathrm{Fe}(\mathrm{mg} / \mathrm{kg})$ & $\mathrm{Zn}(\mathrm{mg} / \mathrm{kg})$ & $\mathrm{Cu}(\mathrm{mg} / \mathrm{kg})$ & $\mathrm{Mn}(\mathrm{mg} / \mathrm{kg})$ & $\mathrm{B}(\mathrm{mg} / \mathrm{kg})$ & $\mathrm{pH}$ \\
\hline 25.00 & 1.40 & 48.17 & 1.22 & 2.58 & 8.11 & 0.19 & 5.9 \\
\hline
\end{tabular}

*Universidad Autonoma de Chiapas, Laboratory of soil analysis. 
samples were stored at $4^{\circ} \mathrm{C}$ and later, used for HPLC analyses.

Analysis HPLC: The analyses were made with a Beckman 126 chromatograph equipped with a diode array detector 168 and an ultrasphere ODS RP 18 column. Compounds were eluted with the following gradient $0-20 \% \mathrm{~B}$ in $\mathrm{A}$ for $1 \mathrm{~min}$, $20 \% \mathrm{~B}$ in $\mathrm{A}-100 \%$ in $20 \mathrm{~min} ; 20 \mathrm{~min} 100 \% \mathrm{~B}$, using $0,1 \%$ TFA (Sigma) in $\mathrm{H}_{2} \mathrm{O}$ as eluent $\mathrm{A}$ and methanol (Baker) as eluent $B$ at a flow rate of 1 $\mathrm{mL} \cdot \mathrm{min}^{-1}$. The detection wavelengths used were 280 and $227 \mathrm{~nm}$. Metabolites were identified by co-chromatography with the reference substance and by UV-scan. The reference substance was synthetic caffeine (Roth) $(\lambda \max =210,273)$.

\section{RESULTS AND DISCUSSION}

\section{Greenhouse conditions}

As result of greenhouse experiments, increase in orthotropic and decrease in plagiotropic growth, as well as reduction in shoot diameter, revealed a possible stimulation of chives and sage avoiding dormancy of apical buds in coffee and decreasing development of productive branches. As pointed by Rice (1984), allelopathic compounds released from plants might be beneficial to the growth of receptor plants, in this case, coffee plants.

Root development in coffee intercalated with aromatic plants was limited as a result of resource competition under plot conditions in the greenhouse. For production variable in aromatic plants, spearmint and chives presented better performance than thyme, sage, and rosemary.

\section{Field conditions}

Interactions between the aromatic species evaluated and coffee plants did not show a negative effect on growing parameters in both crops. In young coffee systems, the interaction of aromatic plants on coffee was positive, increasing appearance of new leaves and demonstrating that spearmint, oregano, and basil were well adapted to coffee plantations and involved a mechanism to tolerate the potentially toxic effects of caffeine.

In this study, basil was highly attractive to grasshoppers (Atractomorpha sinensis) presenting a significant correlation between increase of damage on coffee leaves and intercropping with basil. Whereas, the literature reported negative interactions in soils with more than ten years of continuous production of coffee due to accumulation of caffeine, the data of this study did not show differences among different coffee age systems according to the yield productions of aromatic plants (table 2).

Basil and spearmint were the best treatments for yield production in the three production systems, demonstrating a mechanism to tolerate the potential toxic effects of caffeine.

\section{Laboratory results}

According to Waller et al. (1983), caffeine was absorbed by lettuce seedlings and translocated mainly to the shoots as a possible mechanism for plant to remove alkaloids from the susceptible root tissue after 24 hours of immersion in caffeine solutions of different concentrations.

As a result of this study, all species presented absorption of caffeine and its accumulation was principally in the roots. No presence of caffeine amounts was found in the aerial part of the analyzed tissues, but only traces (table 3). This result can suggest that aromatic seedlings may need more time of immersion to evaluate possible absorption and translocation or that some species are able to metabolize caffeine into another compound. As some aromatic species can absorb caffeine and degrade the compound, it should help to diminish toxic accumulation of the allelochemical in old coffee plantations and increase the production. 
Table 2. Production of aromatic plants under different coffee systems.

\begin{tabular}{|l|c|c|c|}
\hline \multirow{2}{*}{\multicolumn{1}{c|}{ Treatments }} & \multicolumn{2}{|c|}{ Total fresh matter $\mathrm{g} \cdot \mathrm{m}^{-2}$} \\
\cline { 2 - 4 } & Greenhouse & Young plot of land & Old plot of land \\
\hline Italic basil & 107.7 & 96.11 & 110.8 \\
\hline Spearmint & 70.0 & 146.7 & 95.5 \\
\hline Genovese basil & 231.1 & 245.5 & 331.2 \\
\hline Sage & 17.78 & 10.5 & 10.2 \\
\hline Thyme & 26.1 & 23.5 & 14.5 \\
\hline Oregano & 41.1 & 42.2 & 20.7 \\
\hline Chives & 17.76 & 22.5 & 18.4 \\
\hline Rosemary & 9.43 & 6.1 & 5.6 \\
\hline
\end{tabular}

Table 3. Absorption of caffeine after $24 \mathrm{~h}$ incubation.

\begin{tabular}{|l|c|c|c|c|}
\hline \multicolumn{1}{|c|}{ Specie } & $\begin{array}{c}100 \mu \mathrm{M} \\
\text { caffeine root extract nM }\end{array}$ & $\begin{array}{c}100 \mu \mathrm{M} \\
\text { caffeine root extract nM }\end{array}$ & $\begin{array}{c}500 \mu \mathrm{M} \\
\text { caffeine shoot extract } \\
\text { caffeine shoot extract }\end{array}$ \\
\hline Spearmint & 148.8 & 410.3 & no & no \\
\hline Basil & 216.9 & 894.4 & no & no \\
\hline Oregano & 282.6 & 1109.4 & traces & traces \\
\hline Sage & 144.0 & 223.56 & no & traces \\
\hline Thyme & 83.7 & 237.5 & no & traces \\
\hline Rosemary & 461.1 & 1071.36 & no & no \\
\hline Chives & N0 & 226.4 & \\
\hline
\end{tabular}

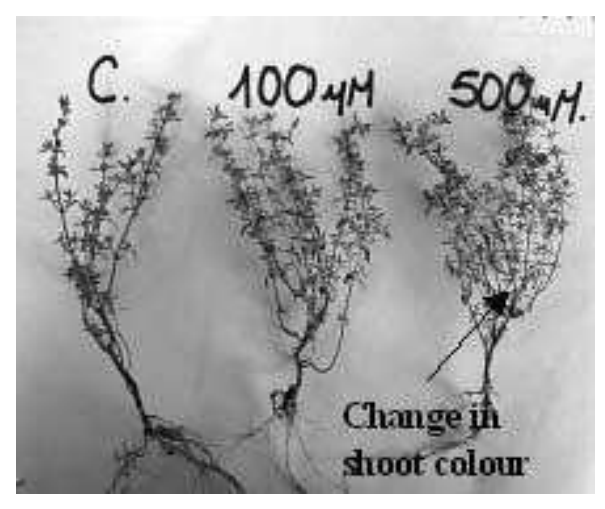

Rosemary after $24 \mathrm{~h}$ incubation

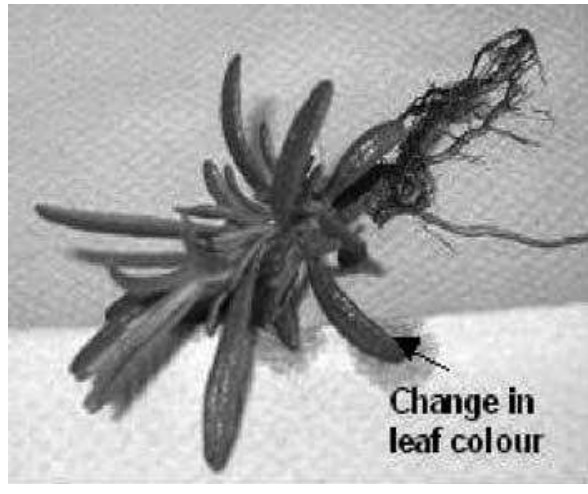

Thyme after $24 \mathrm{~h}$ incubation

Figure 1. Physiological change in Thyme and Rosemary after 24 hrs of incubation in $500 \mu \mathrm{M}$. 


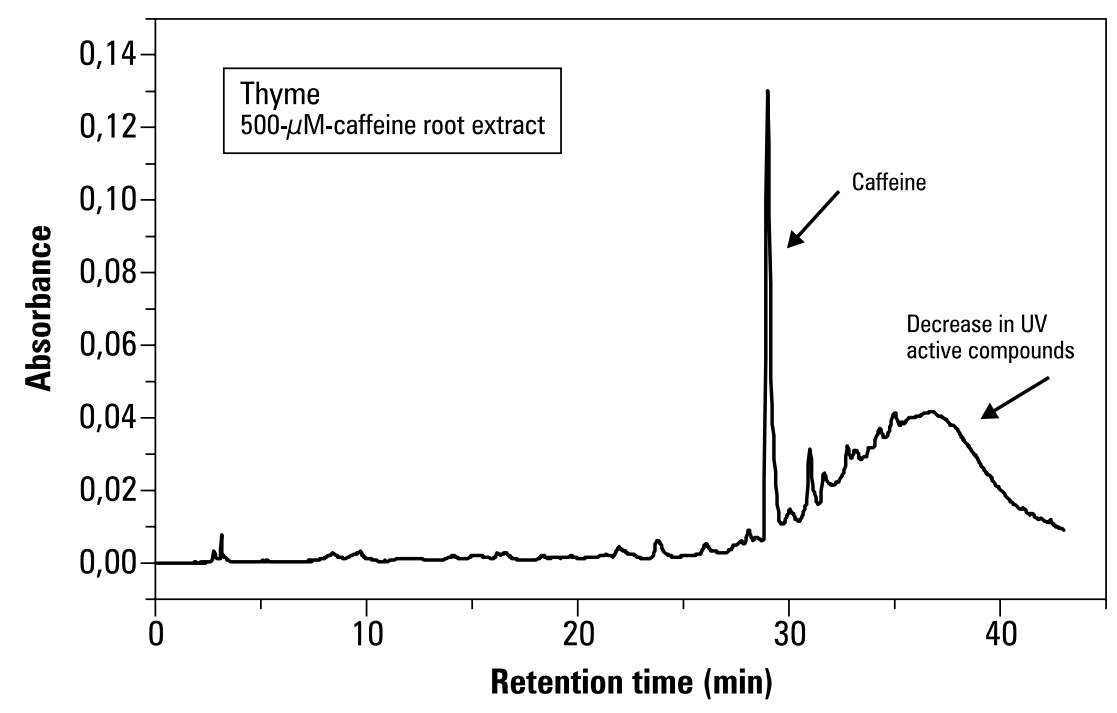

Figure 2. Absorbance of caffeine after $24 \mathrm{~h}$ incubation in thyme root system.

According to the chromatograms, nodetoxification products appeared after uptake and its possible biodegradation was not observed in the analysis, but further studies are necessary to investigate if the alkaloid can be changed upon uptake and translocation in aromatic plants. In sage, thyme and rosemary a change of the smell and color of leaves upon uptake was shown (figure 1).

The results of the studies of caffeine concentration suggest an important protective role of these species. According to Anaya et al. (2002), plants can avoid phytotoxicity by storing toxins (e.g. caffeine, theobromine) into vacuoles or hairy glands, with subsequent change in physical characteristics. Decrease in the concentration and possible change in aromatic compounds can be concluded based on the chromatograms of caffeine uptake of these two species (figure 2, 3).

\section{CONCLUSIONS}

- The results of this study demonstrated that spearmint, oregano, and basil are well adapted to coffee plantations and have involved a mechanism to tolerate the potentially toxic effects of caffeine. Another positive interaction was the increase of branch length and appearance of new leafs in intercropping coffee systems with spearmint and basil compared with the control, showing that the competition and interaction increased the plagiotropic development of productive branches.

- Whereas the literature reported negative interactions in soils with more than ten years of continuous production of coffee due to accumulation of caffeine, the available data in this study did not show differences among coffee systems of different age according to the yield productions of aromatic plants.

- Results demonstrated the high potential of intercropping basil in order to attract coffee pests for future cultural control, while increasing the income for coffee growers.

- Evidence of caffeine uptake and translocation to the roots demonstrated the potential of aro- 


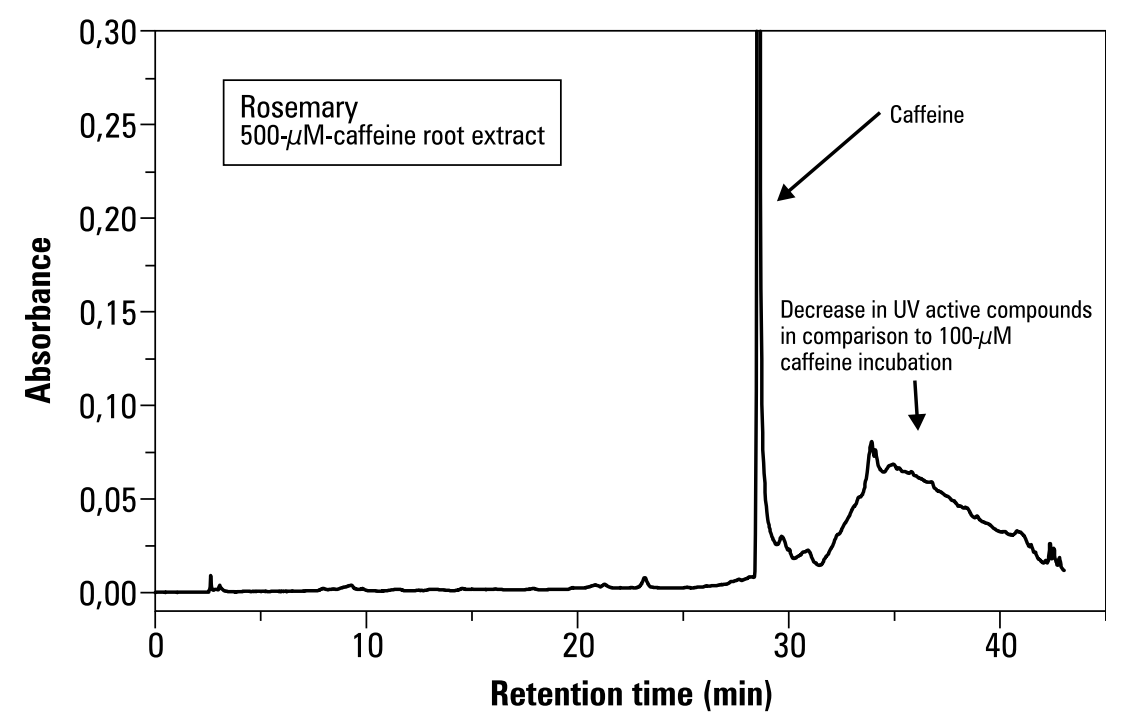

Figure 3. Absorbance of caffeine after $24 \mathrm{~h}$ incubation in rosemary root system.

matic crops in detoxification of coffee soils. Susceptibility of species like sage, thyme, rosemary, and chives to the allelochemical can be concluded on field observations, there, these species did not grow at all. Change in morphological characteristics in thyme and rosemary and decrease of active UV compounds provided strong evidence of possible reaction of plants to phytotoxicity and changes in the chemical characteristics of essential oils.
- Further research remains to be done in order to determine if aromatic plants are able to metabolize caffeine. It is necessary to test which factors affect caffeine uptake, define time and quantity of possible absorption according to the species.

- The intercropping of aromatic plants and coffee would require longer time for exposure plants to interactions and under different seasons and environmental conditions. 


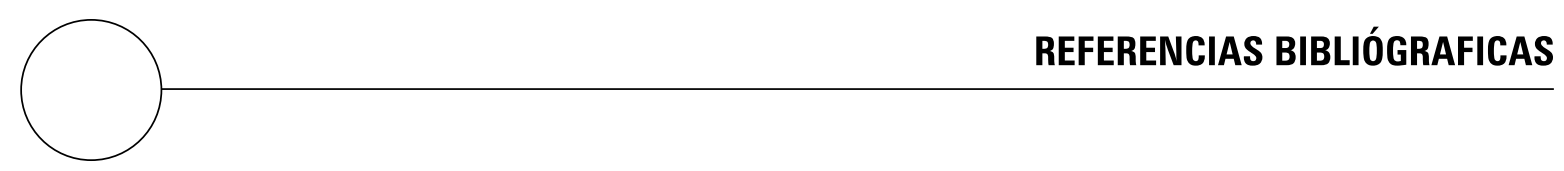

Anaya, A.L.; G.R. Waller; P. Okinda Owuor; J. Friedman; C.H. Chou; T. Suzuki; F. Arroyo-Estrada and R. CruzOrtega. 2002. Overview of caffeine autotoxicity in coffee and tea plantations. pp. 71-91. In: Reigosa, M. and N. Pedrol (eds.) Allelopathy from molecules to ecosystems. Science Publishers, Enfield, USA.

Cárdenas, J. 2003. Crisis cafetalera y perspectivas para los países productores. In: XX Simposio Latinoamericano de Caficultura, San Pedro Sula, Honduras, 28 y 29 de mayo, 2003 (CD-ROM).

Chou, C. H. 1986. The role of allelopathy in subtropical agro ecosystems of Taiwan. In: Putnam, A.R.and C.S. Tang (eds.). The science of allelopathy. John Wiley and Sons, New York.

Chou, C.H. and G.R. Waller. 1980. Possible allelopathic constituent of Coffea arabica L. J. Chem. Ecol. 6, 643-645.

Einhellig, F.A. and G.R. Leather. 1988. Potentials for exploiting allelopathy to enhance crop production. J. Chem. Ecol. 14, 1829-1842.

Friedman, J. and G.R. Waller. 1983. Caffeine hazards and their prevention in germinating seeds of coffee ( $\mathrm{Cof}$ fea arabica L.). J. Chem. Ecol. 9, 1099-1106.

Friedman, J. and G.R. Waller. 1983a. Seeds as allelopathic agents. J. Chem. Ecol. 9, 1107-1115.

Phippen, W.B. and J.E. Simon. 1998. Anthocyanins in basil (Ocimum basilicum L.). J. Agr. Food Chem., 1734-1738.
Phippen, W.B. and J.E. Simon. 2000. Anthocyanin inheritance and instability in purple basil (Ocimum basilicum L.). J. Hered. 91, 289-296.

Pohlan, J. 2002. México y la cafeticultura chiapaneca - reflexiones y alternativas para los cafeticultores. Verlag Shaker, Aachen, Germany. 386 p.

Pohlan, J. 2001. Ökologischer Obstanbau - eine Alternative zum Kokaanbau im Departamento Cauca, Kolumbien. J. Agr. Trop. Subtropics 102 (2), 169-183.

Rice, E. L. 1984. Allelopathy, $2^{\text {nd }}$ ed. Academic, Orlando, $\mathrm{FL}, 422 \mathrm{p}$.

Rizvi, S. J. H. and V. Rizvi. 1987. Improving crop productivity in India: Role of allelochemicals. In: Waller G. R. (ed). Allelochemicals: Role in agriculture and forestry. ACS Symposium series 330. Washington D.C.

Suzuki, T. and G.R. Waller. 1987. Allelopathic due to purine alkaloids in tea seeds during germination. Plant Soil 98, 131-136.

Waller, G.R.; D.C. MacVean and T. Suzuki. 1983. Plant Cell Rep. 2, 109-112.

Waller, G. R.; J. Friedman; C. H Chou; T. Suzuki and N. Friedman. 1986. In: Proceedings of the Seminar on Allelochemicals and Pheromones. Monograph 5. Institute of Botany, Academia Sinica, Taipei, ROC, pp. 239-260. 